\title{
Mob Lynching: A New Form of Hate Crime
}

\author{
Manoj Kumar Pathak ${ }^{1}$, Srishti Rai ${ }^{2}$ \\ ${ }^{1}$ Professor and Head, ${ }^{2}$ Research Scholar, Forensic Medicine, Department of Forensic Medicine, Institute of \\ Medical Sciences, Banaras Hindu University, Varanasi, India
}

\begin{abstract}
Lynching is a form of extrajudicial execution by hanging carried out by mob, which is functioning independently of local police and law enforcement authorities. Indian also faced Indian WhatsApp lynching, which are a spate of Mob-related violence and killing following the spread of rumours, primarily relating to child-abduction and organ harvesting, via the WhatsApp message service. They fall under the category of organised hate crimes. According to the source from internet, it has been observed a rise in mob lynching cases related to cow vigilantism by over $10 \%$. It is important to note that India does not have one comprehensive parliamentary law on mob lynching. Strong provisions of law and speedy convictions in mob lynching cases will act as deterrence for the society.
\end{abstract}

Keywords: Lynch, WhatsApp lynching, cow vigilantism, child lifters

\section{Introduction}

The origin of the word "lynch" are obscure, but it likely originated during the American Revolution. The verb comes from the phrase "Lynch Law" a term for a punishment without trial. Two Americans during this era are generally credited for coining the phrase: Charles Lynch and William Lynch. ${ }^{[1]}$

Lynching is a form of extrajudicial execution by hanging carried out by mob, which is functioning independently of local police and law enforcement authorities. ${ }^{[2]}$ However, now a days it has become a wider term and may be defined as an act or a series of act by a group of people which forms an unlawful assembly, takes law in their own hands and commit crime against an individual or a group of individual to impose their own extra judicial punishments. In India lynching reflects, internal tensions between ethnic communities, communities sometimes lynch accused or suspicious convicts. There have been numerous lynching in relation to cow vigilante violence in India since 2014 mainly

\section{Corresponding Author:}

Dr. Manoj Kumar Pathak, Professor and Head, Forensic Medicine Department of Forensic Medicine, Institute of Medical Sciences, Banaras Hindu University, Varanasi-221005, India: Mobile No.9450179177: Email-drmanojpathak@gmail.com involving Hindu mobs lynching Indian Muslims and Dalits $^{[1]}$

Indian also faced Indian WhatsApp lynching, which are a spate of Mob-related violence and killing following the spread of rumours, primarily relating to child-abduction and organ harvesting, via the WhatsApp message service.

Mob violence, vigilant justice and outbreaks of mass panics have a long history in India, but they have tended to be localized events. What differentiates the Indian WhatsApp lynching of 2017-2018 is that social media has enabled acts of violence to be filmed and shared across the country in such a way to build upon and perpetuate an atmosphere of fear and misinformation that instigate further violence in unconnected locations. For example, video of a lynching in Karnataka has been linked to a spate of violent lynching in Maharashtra. ${ }^{[3]}$

What is lynching?

Lynching is a type of non-justifiable homicidal hanging. It is difficult for a single assailant to carry it out. Lynching is an extrajudicial execution carried out by a mob by hanging without a fair trial ${ }^{[4]}$

They fall under the category of organised hate crimes. Now-a-days it has got a wider meaning and also 
includes acts of violence by a mob against a person or a group of people whom they suspect of having done an act which the group of people do not approve it. In this process they take law in their own hands and do not wait for a fair trial to be conducted.

Causes of Mob Lynching in INDIA

- Rise of cow vigilante
- Silence of political class

- Rumours of child lifters [5]

- For personal enmity

- In cases of sexual violence

What the statistics say:

TABLE: 1: Cow related violence in India [source: internet]

\begin{tabular}{|c|c|c|c|c|c|c|c|}
\hline \multirow{2}{*}{ Year } & \multirow{2}{*}{ Incidents } & \multirow{2}{*}{ Victims } & \multirow{2}{*}{ Death } & \multirow{2}{*}{$\begin{array}{l}\text { Major } \\
\text { assaults }\end{array}$} & \multirow{2}{*}{$\begin{array}{l}\text { Minor } \\
\text { injuries }\end{array}$} & \multicolumn{2}{|c|}{ Gender } \\
\hline & & & & & & $\mathbf{M}$ & $\mathbf{F}$ \\
\hline 2012 & 1 & 2 & 0 & 0 & 2 & $100 \%$ & \\
\hline 2013 & 2 & 1 & 0 & 0 & 1 & N/A & N/A \\
\hline 2014 & 3 & 11 & 0 & 11 & 0 & $100 \%$ & \\
\hline 2015 & 13 & 49 & 11 & 34 & 4 & $95 \%$ & $5 \%$ \\
\hline 2016 & 30 & 67 & 9 & 40 & 18 & $75 \%$ & $14 \%$ \\
\hline 2017 & 43 & 108 & 13 & 64 & 31 & $85 \%$ & $9 \%$ \\
\hline 2018 & 31 & 57 & 13 & 17 & 27 & $93 \%$ & $3 \%$ \\
\hline 2019 & 10 & 45 & 4 & 14 & 27 & $88 \%$ & $13 \%$ \\
\hline
\end{tabular}

\section{Cases:}

A software professional from Hyderabad was lynched while three of his friends including a Qatar national were thrashed by a mob which suspected them to be child-kidnappers, at Kamalnagar in Bidar district of Karnataka.

The victim was a 32 year male, who is married and has a two-year-old son. He was an employee of Google in Gachibowli and was a resident of Errakunta on the outskirts. According to his family members, he and his friends including the Qatar national had gone to Murki village in Bidar to attend a function at a friend's place. The group was travelling in a car and stopped near a government school for a break in the Kamalnagar police station area. "one of them had brought chocolates from Qatar and offered them to some children who were coming out of the school. Villagers who saw this tried to catch them but the group noticed them and tried to flee. They were stopped by a mob at another village and assaulted," victim's younger brother said.[6]

Muslim man was attacked by a mob in Kharsawan district of Jharkhand on the suspicion of theft on June 18. He was beaten up mercilessly for over 18 hours before being handed over to the police. He succumbed to his injuries at a local hospital on June 22. The victim has been identified as 24-year-old male. Several videos of the Jharkhand mob lynching have gone viral since the incident. In one of the videos, a man is seen hitting the victim with a wooden stick as the latter begs him to let 
him go. Another video showed the victim being forced to chant "Jai Shri Ram" and "Jai Hanuman".

On the night of June 18, he left his village for Jamshedpur with two men. Aurungzeb Ansari, a Jharkhand-based activist, has claimed that the victim was unaware where the two men were taking him. Ansari told HuffPost India that the victim was manipulated to go with them. While the two men fled the crime scene, the mob caught the victim and started beating him up. "Ghar mein ghusega [You will enter the house?]," one of the men is heard asking the victim. The victim is, however, heard denying the charges and said that the two other men did and he was asked to wait near the motorcycle. "I did not know anything," he said. Towards the end of one of the videos, one of the men asks him to chant "Jai Shri Ram" and "Jai Hanuman".[7]
2016 Jharkhand mob lynching refers to the case of lynching of two Muslim cattle traders by allegedly Cattle-Protection Vigilantes in Balumath forests in Latehar district in Jharkhand on 18 March 2016. The attackers killed 32 years old man and 12 years old boy who were found hanging from a tree. According to Jharkhand police, preliminary investigation revealed that the two were on their way to a cattle market in Chatra district. They had at least eight oxen with them, which they intended to sell. They were reportedly caught by a group of people in the early hours, beaten to death and hanged. According to villagers, there were communal clashes over beef eating in the area three months ago. Police stated the murder was aimed at looting money and cattle. Police arrested 5 people and are looking for three others, also said to be involved in the murders. One of the accused has links to a local Gau Raksha Samiti (an outfit for protection of cows). ${ }^{[8]}$

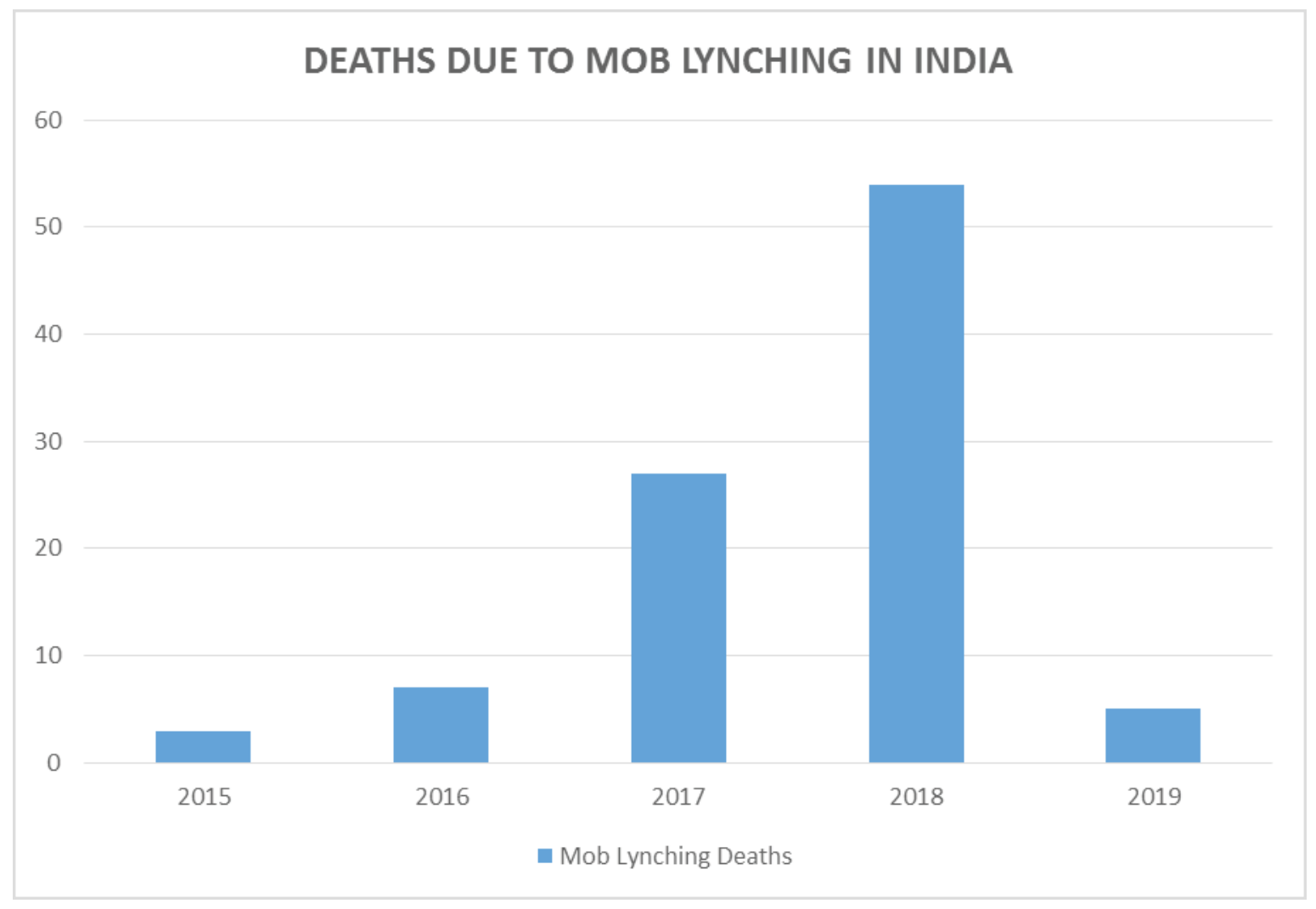

FIGURE: 1; Source: Google Images

Laws on mob lynching:

Laws that already exist and may aid in the lynching cases

CrPC 129: Any Executive Magistrate or office in charge of a police station or, in the absence of such officer 
in charge, any police officer, not below the rank of a sub-inspector, may command any unlawful assembly, or any assembly of five or more persons likely to cause a disturbance of the public peace, to disperse; and it shall thereupon be the duty of the members of such assembly to disperse accordingly.

If, upon being so commanded, any such assembly does not disperse, or if, without being so commanded, it conducts itself in such a manner as to show a determination, not to disperse, any Executive Magistrate or police officer referred to in Sub-Section (1), may proceed to disperse such assembly by force, , for the purpose of dispersing such assembly, and, if necessary, arresting and confining the persons who form part of it, in order to disperse such assembly or that they may be punished according to law ${ }^{[9]}$.

IPC 302: Punishment for murder.-whoever commits murder shall be punished with death, or 1 [imprisonment for life], and shall also be liable to fine. [10]

IPC- 304: Punishment for culpable homicide not amounting to murder: imprisonment for life, or up to 10 years and also fine. " provided that if death is caused to a girl or a women, the accused committing such homicide shall be punished with imprisonment for whole life and shall also be liable for fine which may extend to two lakh rupees. ${ }^{[11]}$

Guidelines laid down by Supreme Court

A three-judge bench of Chief Justice Dipak Misra and Justices A.M. Khanwilkar and D.Y. Chandrachud also urged Parliament to frame a special legislation to tackle the problems posed by vigilante squads and said that until then the guidelines would stand the force of law.

\section{The guidelines}

- The states shall designate a senior police officer not below the rank of police superintendent as nodal officer in each district. These officers will set up a task force to be assisted by one DSP-rank officer for taking measures to prevent mob violence and lynching. The task force will gather intelligence reports of people likely to commit such crimes or who are involved in spreading hate speeches, provocative statements and fake news

- The state governments shall immediately identify districts, sub-divisions and villages where instances of lynching and mob violence have been reported in the recent past. The process of identification should be done within a period of three weeks from the date of the judgment

- The nodal officer shall hold regular meetings (at least once a month) with the local intelligence units in the districts and station house officers to identify tendencies of vigilantism and mob violence.

- The director-general of police or the home department secretary shall hold regular review meetings (at least once a quarter) with all the nodal officers and state police intelligence heads

- All police officers will have to ensure the dispersal of mobs that have a tendency to cause violence or lynch in the garb of vigilantism or otherwise

- The DGP shall issue a circular to the SPs on police patrolling in sensitive areas

- The central and state governments should broadcast on radio, television and other media platforms, including the official websites of the home department and the state police, that lynching and mob violence will invite serious consequence

- The police shall register FIRs under Section 153A of the IPC (promoting enmity among people) and/or other relevant provisions against the perpetrators

\section{Remedial measures}

- Despite the preventive measures taken by the state police, if it comes to the notice of the local police that an incident of lynching or mob violence has taken place, the jurisdictional police station shall immediately lodge an FIR

- It shall be the duty of the station house officer to immediately intimate the nodal officer in the district who shall, in turn, ensure that there is no further harassment of the family members of the victim(s)

- The investigation in such offences shall be personally monitored by the nodal officer, who shall be duty-bound to ensure that the investigation is carried out effectively and the charge sheet filed within the statutory period

- The cases of lynching and mob violence shall be specifically tried by designated courts in each district. Such courts shall try cases on a day-to-day basis. The 
trial should preferably be concluded within six months.

Deterrent punishment

- The trial court must ordinarily award the maximum sentence under the provisions of the IPC

- The courts may, on application by a witness or by the public prosecutor, take such measures as it deems fit, for protection and for concealing the identity and address of the witness

It is important to note that India does not have one comprehensive parliamentary law on mob lynching. In 2017 K.T.S Tulsi introduced a draft bill in Rajya Sabha. But the bill has never been debated upon and has not been passed till date.

Some of the bills that have been passed regarding mob lynching are:

\section{U.P combating of mob lynching bill.}

[not passed yet]

As per the available data from 2012 to 2019, 50 incidents of mob violence have taken place in Uttar Pradesh. Of around 50 victims, 11 have died. Twenty-five of these were cases of major assault, including those by cow vigilantes (Gau-Rakshak). The Uttar Pradesh Law Commission has submitted a draft Bill recommending up to life imprisonment for mob lynching crimes.

The chairman of the Commission, Justice (retd.) AN Mittal submitted the report on mob lynching, along with the draft Bill to Chief Minister Yogi Adityanath.
The Commission said the existing laws were not sufficient to combat lynching and asserted that there should be a separate law to tackle them. It suggested a punishment ranging from seven years in jail to life imprisonment for the offence. ${ }^{[13]}$

The Rajasthan Protection from Lynching bill.

Rajasthan Legislative Assembly on August 6, 2019, passed a bill against mob lynching and honour killing in the state.

- The anti-mob-lynching bill proposes imprisonment up to seven years and a fine up to Rs. 1 lakh in case of the victim suffering simple injuries.

- The convicts will get jail terms up to 10 years and a fine of Rs. 25,000 to Rs. 3 lakh in case of an assault by mob or victim suffering serious injuries.

- In case of victim's death, the Rajasthan Protection from Lynching Bill, 2019 provides for life imprisonment and a fine from Rs. 1 to 5 lakh to those convicted in cases of mob lynching. $\left.{ }^{[14}\right]$

The West Bengal (Prevention of Lynching) Bill

The legislation, which has provision for the death sentence, says "nodal officers" will be appointed to "monitor and coordinate prevention of lynching". It proposes a jail term from three years to life for those involved in assaulting and injuring a person. The Bill, while defining terms such as "lynching" and "mob", says the West Bengal Lynching Compensation Scheme may be framed under this Act. ${ }^{[15]}$

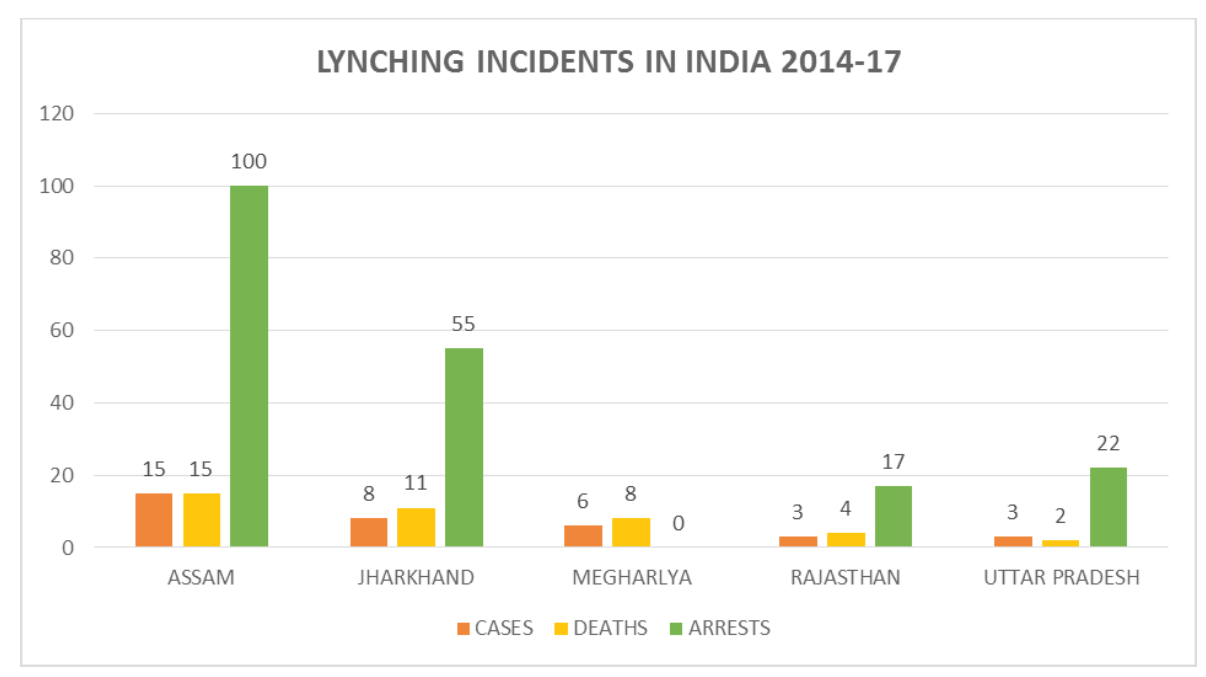

FIGURE: 2; Source: Google Images 


\section{Conclusion}

Mob lynching is a type of organised hate crime conducted by a crazy mob. People should have empathy towards such crime and not the apathy attitude. Government should address this issue very seriously at least in states where the incident rate is very high on priority basis. It is necessary to have separate law in the IPCs to address lynching and honour killing crimes as there are no specific laws to address these crimes. If necessary separate and new sections should be incorporated in the IPC as there is a new and separate section to deal with acid attack cases i.e., section 326A and $326 \mathrm{~B}$. It is unfortunate that this crime is ignored from government's end till date. Strong provisions of law and speedy convictions in mob lynching cases will act as deterrence for the society.

Acknowledgement: Authors would like to thank print and electronic media for providing us with immense resource materials in preparation of this article.

\section{Conflict of Interest: Nil}

Source of Funding: This research was financially supported by UGC.

Ethical Clearance: The present study was approved by "Institutional Ethical Committee" of Institute of Medical Sciences, Banaras Hindu University, Varanasi. All the information has been taken under consideration of medical ethical committee.

Statement of Informed consent: This is a review study done by going through various online contents. No consent was required.

\section{References}

1. Lynching [Internet]. En.wikipedia.org. 2019 [cited 7 September 2019]. Available from: https:// en.wikipedia.org/wiki/Lynching

2. lynching [Internet]. TheFreeDictionary.com. 2019 [cited 6 September 2019]. Available from: https:// medical-dictionary.thefreedictionary.com/lynching

3. Indian WhatsApp lynchings [Internet]. En.wikipedia.org. 2019 [cited 2 September 2019]. Available from: https://en.wikipedia.org/wiki/ Indian_WhatsApp_lynchings

4. Aggrawal A. Textbook of FORENSIC MEDICINE and TOXICOLOGY. Avichal Publishing Company; 2016.
5. Lynching in India, mob violence, mob violence in India, causes and consequences of mob violence in India, mob violence in India UPSC [Internet]. Civilserviceindia.com. 2019 [cited 10 September 2019]. Available from: https://www. civilserviceindia.com/current-affairs/articles/ rising-mob-violence-in-india.html

6. Mob lynches Google techie on child-lifting suspicion in Karnataka [Internet]. The Asian Age. 2019 [cited 12 September 2019]. Available from: https://www.asianage.com/india/all-india/150718/ mob-lynches-google-techie-on-child-liftingsuspicion-in-karnataka.html

7. Desk. Jharkhand: Muslim man beaten up on suspicion of theft, forced to chant Jai Shree Ram, succumbs to injuries [Internet]. India Today. 2019 [cited 12 September 2019]. Available from: https://www.indiatoday.in/india/story/ jharkhand-muslim-man-lynching-jai-shree-ramjai-hanuman-1554634-2019-06-23

8. 2016 Jharkhand mob lynching [Internet]. En.wikipedia.org. 2019 [cited 14 September 2019]. Available from: https://en.wikipedia.org/ wiki/2016_Jharkhand_mob_lynching

9. CrPC Section 129 - Dispersal of assembly by use of civil force [Internet]. A Lawyers Reference. 2019 [cited 12 September 2019]. Available from: https://devgan.in/crpc/section/129/

10. IPC Section 302 - Punishment for murder [Internet]. A Lawyers Reference. 2019 [cited 07 September 2019]. Available from: https://devgan.in/ipc/ section/302/

11. Reddy KSN. The Essentials of Forensic Medicine and Toxicology. 33rd edition. Jaypee Brothers Medical Publishers; 2014.

12. SC lays down guidelines to curb lynching [Internet]. Telegraphindia.com. 2019 [cited 09 September 2019]. Available from: https://www. telegraphindia.com/india/sc-lays-down-guidelinesto-curb-lynching/cid/1351483

13. Service. Lucknow: UP law panel recommends life term for mob lynching crimes [Internet]. India Today. 2019 [cited 09 September 2019]. Available from: https://www.indiatoday.in/india/story/ lucknow-up-law-panel-recommends-life-term-formob-lynching-crimes-1567286-2019-07-12

14. AFFAIRS C, Affairs E, Bakshi G. Rajasthan Assembly passes anti-mob lynching bill, convicts 
to get life imprisonment [Internet]. Jagranjosh. com. 2019 [cited 09 September 2019]. Available from: https://www.jagranjosh.com/current-affairs/ rajasthan-assembly-passes-antimob-lynching-billconvicts-to-get-life-imprisonment-1565175378-1
15. West Bengal assembly passes bill against mob assault, lynching [Internet]. Businesstoday.in. 2019 [cited 09 September 2019]. Available from: https:// www.businesstoday.in/current/economy-politics/ west-bengal-assembly-passes-bill-against-mobassault-lynching/story/376542.html 